\title{
Analysis of the opinions of medical community and patients regarding legal regulations on the profession of physiotherapist in Poland
}

A - preparing concepts (opracowanie koncepcji i założeń)

B - formulating methods (opracowanie metod)

$\mathrm{C}$ - conducting research (przeprowadzenie badań)

$\mathrm{D}$ - processing results (opracowanie wyników)

E - interpretation and conclusions (interpretacja i wnioski)

F - editing the final version (redakcja ostatecznej wersji)

\section{Analiza opinii środowiska medycznego oraz pacjentów na temat prawnych regulacji wykonywania zawodu fizjoterapeuty w Polsce}

\author{
Dalia Woźnica A-F
}

Department of Physiotherapy, Faculty of Health Sciences, Department of Rehabilitation, Medical University of Gdansk, Zakład Fizjoterapii, Wydział Nauk

o Zdrowiu, Katedra Rehabilitacji, Gdański Uniwersytet Medyczny

\section{Abstract}

Introduction: Physiotherapists have been calling for regulations regarding their job for years. The main reasons for their fight to implement these regulations included caring about patients' safety, improving the quality of services and increasing professional independence. In September 2015, the President of Poland signed the Act on the Profession of Physiotherapist (APP). The controversial items in the Act mainly referred to the Professional Self-Government as well as rights and duties of physiotherapists. The aim of the work was to analyse and compare the opinions of medical community members (including physiotherapists) as well as patients on the key guidelines of the APP.

Material and methods: A questionnaire that included 20 questions regarding the guidelines of the APP was applied in the study. Internet links to the questionnaire were sent via email to randomly selected respondents from three groups, i.e. physiotherapists $(\mathrm{PT})$, representatives of other medical professions (OMP) and patients (P).

Results: The author received 177 completed questionnaires (PT $n=67$, OMP $n=40$, $\mathrm{P} n=70)$. The majority of the respondents in all the groups were 20-40 years of age (PT, OMP, P). Doctors of various specialisations constituted $67 \%$ of the OMP group. In this group, $17.5 \%$ of the respondents did not approve of the professional self-government of physiotherapists, while in the $\mathrm{P}$ group, $17 \%$ of the respondents expressed the same opinion. The majority of the respondents in all the groups ( $\mathrm{P}-54 \%$, OMP $-70 \%$, PT $-85 \%$ ) believed that physiotherapists should select physiotherapeutic procedures independently. In turn, $15 \%$ of the respondents from the OMP group, $21 \%$ from the $\mathrm{P}$ group and $7.5 \%$ from the PT group indicated that procedures should be selected by a rehabilitation doctor.

Conclusions: It was noted that there is a need for raising awareness regarding the job of a physiotherapist and for promoting it in the society but also among the representatives of OMP. Legal changes on the market of services provided by physiotherapists require educating in terms of new legal regulations. There is also a need for further research on opinions regarding the changes in the physiotherapy sector.

Key words:

rehabilitation, legal regulations, the Act on the Profession of Physiotherapist

email: daliawoznica@gumed.edu.pl

The study was financed from the authors' own resources.

Badania zostały sfinansowane ze środków własnych 


\section{Streszczenie}

Wstęp: Fizjoterapeuci (FT) od lat ubiegali się o regulacje zawodowe. Głównym powodem walki o ustawę była troska o bezpieczeństwo pacjentów, podniesienie jakości usług oraz zwiększenie samodzielności zawodowej. We wrześniu 2015 roku, prezydent podpisał Ustawę o Zawodzie Fizjoterapeuty (UZF). Punkty sporne ustawy dotyczyły głównie samorządu, praw i obowiązków FT. Celem pracy była analiza i porównanie opinii środowiska medycznego (w tym FT), a także pacjentów, na temat kluczowych założeń, jakie wprowadza UZF.

Materiał i Metody: Posłużono się ankietą, złożoną z 20 pytań dotyczących założeń UZF. Linki $\mathrm{z}$ ankietą rozesłano losowo drogą mailową do trzech grup respondentów: fizjoterapeutów (F), przedstawicieli innych zawodów medycznych (IZM), pacjentów (P).

Wyniki: Odebrano zwrotnie 177 ankiet: $F \mathrm{n}=67$, IZM n=40, P $\mathrm{n}=70$. We wszystkich grupach najwięcej ankietowanych znalazło się w przedziale wiekowym 20-40 lat (F IZM P). Grupę IZM w 67\% tworzyli lekarze różnych specjalizacji. W grupie IZM 17,5\% a w grupie P 17\% respondentów nie popiera utworzonego samorządu zawodowego FT. Większość respondentów we wszystkich grupach uważa, że FT powinien samodzielnie ustalać zabiegi fizjoterapeutyczne (odpowiednio: P 54\%, IZM 70\%, F 85\%). Na lekarza rehabilitacji jako zlecającego zabiegi wskazało odpowiednio: IZM 15\%, P 21\% i F 7,5\% osób.

Wnioski: Zauważa się potrzebę zwiększenia świadomości znaczenia zawodu FT, jego promocję w społeczeństwie ale także i wsród przedstawicieli IZM. Wprowadzane zmiany legislacyjne na rynku usług FT wymagają edukacji pod kątem nowych regulacji prawnych. Rysuje się także potrzeba kontynuacji badań opinii na temat zachodzących zmian w sektorze fizjoterapii.

Słowa kluczowe: rehabilitacja, regulacje prawne, ustawa o zawodzie fizjoterapeuty

\section{Introduction}

The professional community of physiotherapists, who constitute the third biggest medical profession, have been calling for legal regulations regarding their job for over 30 years [1]. The main reasons for their fight to implement these regulations included caring about patients' safety, improving the quality of services and increasing professional independence. In September 2015, the President of Poland signed the Act on the Profession of Physiotherapist (APP). The Committee of the Organisation of the Professional Self-Government of Physiotherapists was created to watch whether the conditions of implementing the Act were observed. In December 2016, the first Polish Congress of Delegates was held aimed at forming the Professional SelfGovernment of Physiotherapists and putting forward the first resolutions for the beginning of the 4-year term of office. Poland became the next country in Europe which has the Professional SelfGovernment of Physiotherapists represented by the Polish Chamber of Physiotherapists (PChP) and the Polish Council of Physiotherapists (PCP) currently accepting the first right to practise the profession.
The controversial items in the Act regarded mainly the Professional Self-Government, rights and duties of physiotherapists as well as their professional independence. Despite the fact that the Act came into force, the controversial items may still divide certain communities and lead to a heated debate. A new situation and the lack of detailed knowledge about legal regulations also raise many questions and doubts among physiotherapists.

The aim of the work was to analyse and compare the opinions of medical community members (including physiotherapists) as well patients on the key guidelines of the APP.

The following hypothesis was formulated:

There exist differences between the opinions on the APP expressed by the examined groups.

\section{Material and methods}

An Internet link to the anonymous questionnaire was sent via email to three groups of respondents, i.e. physiotherapists (PT), representatives of other medical professions (OMP) and patients $(\mathrm{P})$. The questionnaire included 20 questions which referred to key aspects of the Act, i.e. the self-government, 
rights and duties of physiotherapists, their professional independence and education. In each group, 100 links to the questionnaire were sent to randomly selected email addresses collected at the Regional Hospital in Koszalin and Swissmed Hospital in Gdansk. Email addresses in the PT group were obtained from the data bases of the Polish Physiotherapy Association (PPA) and the Polish Society of Physiotherapy (PSP).
The author received 40 properly completed questionnaires from the OMP group, 67 from the PT group and 70 from the $\mathrm{P}$ group. The majority of the respondents in all the groups were 20-40 years of age (OMP - 62.5\%; P-67\%; PT - 76\%). Doctors of various specialisations constituted $67 \%$ of the OMP group (Table 1). The comparative analysis of the three examined groups was performed with the use of the chi-square test.

Tab. 1. OMP group

\begin{tabular}{|c|c|c|c|c|c|}
\hline OMP & $n=40$ & $\%$ & OMP & $\mathrm{n}=\mathbf{4 0}$ & $\%$ \\
\hline internal medicine specialist & 7 & 17.5 & paediatrician & 2 & 5 \\
\hline orthopaedist & 5 & 13 & neuropsychologist & 1 & 2.5 \\
\hline nurse & 4 & 10 & dentist & 1 & 2.5 \\
\hline neurologist & 3 & 7 & neonatology specialist & 1 & 2.5 \\
\hline radiologist & 2 & 5 & pharmacist & 1 & 2.5 \\
\hline surgeon & 1 & 2.5 & nephrologist & 1 & 2.5 \\
\hline
\end{tabular}

\section{Results}

On average, $78 \%$ of the respondents from the $\mathrm{P}$ and OMP groups used the services of physiotherapists and rehabilitation doctors within the last 5 years. The majority of the patients visited a physiotherapist in a private sector, compared to the number of patients using state healthcare (71.4\% and 8.6\%, respectively) (Table 2).

Tab. 2. The percentage of respondents in the $\mathrm{P}$ and OMP groups who visited physiotherapists and rehabilitation doctors in a private and state sector

\begin{tabular}{|l|l|l|l|l|l|}
\hline Physiotherapist & OMP & P & Rehabilitation Doctor & OMP & P \\
\hline Total & $77.5 \%$ & $80 \%$ & Total & $82.5 \%$ & $72 \%$ \\
\hline Private sector & $\mathbf{4 2 . 5 \%}$ & $\mathbf{7 1 . 4 \%}$ & Private sector & $\mathbf{0}$ & $\mathbf{1 6 \%}$ \\
\hline State sector & $35 \%$ & $8.6 \%$ & State sector & $82.5 \%$ & $56 \%$ \\
\hline
\end{tabular}

Tab. 3. Questions included in the questionnaire and the percentage of answers in particular groups. 1: yes, doctors of various specilisations should select physiotherapeutic procedures; 2: yes, but only rehabilitation doctors should select physiotherapeutic procedures; 3: no, a person with Master's degree in physiotherapy should select physiotherapeutic procedures; 4: it should be studied at the university that gives a possibility to obtain a Master's degree; 5: it should be studied at a 2-year vocational college that gives a possibility to obtain a Technician's degree

\begin{tabular}{|c|c|c|c|c|}
\hline Questions & Possible answers & OMP $n=40$ & PT n $=67$ & $\mathrm{P} n=70$ \\
\hline $\begin{array}{l}\text { Do you think physiotherapists should work according to } \\
\text { medical doctor's orders? }\end{array}$ & $\begin{array}{l}1 \\
2 \\
3 \\
\text { I don't know }\end{array}$ & $\begin{array}{l}7.5 \% \\
15 \% \\
70 \% \\
7.5 \%\end{array}$ & $\begin{array}{l}7.5 \% \\
7.5 \% \\
85 \% \\
0\end{array}$ & $\begin{array}{l}10 \% \\
21 \% \\
54 \% \\
6 \%\end{array}$ \\
\hline Patient with back pain should FIRST go to...? & $\begin{array}{l}\text { General Practitioner } \\
\text { Orthopaedist } \\
\text { Physiotherapist } \\
\text { Rehabilitation Doctor } \\
\text { Neurosurgeon }\end{array}$ & $\begin{array}{l}5 \% \\
5 \% \\
55 \% \\
25 \% \\
7.5 \%\end{array}$ & $\begin{array}{l}3.5 \% \\
4.5 \% \\
67 \% \\
19 \% \\
6 \%\end{array}$ & $\begin{array}{l}4.5 \% \\
6 \% \\
44 \% \\
21.5 \% \\
24 \%\end{array}$ \\
\hline $\begin{array}{l}\text { Do you think that the profession of physiotherapist should } \\
\text { be studied? }\end{array}$ & $\begin{array}{l}4 \\
5\end{array}$ & $\begin{array}{l}92.5 \% \\
7.5 \%\end{array}$ & $\begin{array}{l}91 \% \\
9 \%\end{array}$ & $\begin{array}{l}94 \% \\
6 \%\end{array}$ \\
\hline Do you approve of 4-year specialisation in physiotherapy? & $\begin{array}{l}\text { Yes } \\
\text { Professional } \\
\text { No } \\
\text { I don't know }\end{array}$ & $\begin{array}{l}22.5 \% \\
50 \% \\
10 \% \\
17.5 \% \\
\end{array}$ & $\begin{array}{l}13 \% \\
66 \% \\
15 \% \\
6 \% \\
\end{array}$ & $\begin{array}{l}26 \% \\
54 \% \\
6 \% \\
14 \% \\
\end{array}$ \\
\hline
\end{tabular}


Tab. 4. Questions included in the questionnaire and the percentage of answers in particular groups, i.e. OMP, PT and P. DY (definitely yes), RY (rather yes), N (no), DK (don't know).

\begin{tabular}{|c|c|c|c|c|}
\hline Questions & Possible answers & OMP n=40 & PT n=67 & $\begin{array}{l}P \\
n=70\end{array}$ \\
\hline Do you think physiotherapy is a medical science? & $\begin{array}{l}\text { DY } \\
\text { RY } \\
\mathrm{N}\end{array}$ & $\begin{array}{l}62.5 \% \\
30 \% \\
\mathbf{7 . 5 \%}\end{array}$ & $\begin{array}{l}91.5 \% \\
7.5 \% \\
1 \%\end{array}$ & $\begin{array}{l}73 \% \\
24 \% \\
3 \%\end{array}$ \\
\hline Do you think physiotherapy is a profession of public trust? & $\begin{array}{l}\text { DY } \\
\text { RY } \\
\mathrm{N} \\
\end{array}$ & $\begin{array}{l}70 \% \\
25 \% \\
5 \% \\
\end{array}$ & $\begin{array}{l}92.5 \% \\
7.5 \% \\
0\end{array}$ & $\begin{array}{l}73 \% \\
11 \% \\
6 \% \\
\end{array}$ \\
\hline $\begin{array}{l}\text { Do you know the main guidelines of the new Act on the Profession } \\
\text { of Physiotherapist? }\end{array}$ & $\begin{array}{l}\text { DY } \\
\text { RY } \\
\text { DK }\end{array}$ & $\begin{array}{l}15 \% \\
37.5 \% \\
47.5 \%\end{array}$ & $\begin{array}{l}60 \% \\
40 \% \\
0 \\
\end{array}$ & $\begin{array}{l}8.5 \% \\
37 \% \\
\mathbf{5 4 . 5 \%}\end{array}$ \\
\hline $\begin{array}{l}\text { Do you think a person with Master's degree in physiotherapy } \\
\text { should select rehabilitation supporting devices (e.g. orthoses, } \\
\text { crutches)? }\end{array}$ & $\begin{array}{l}\text { DY } \\
\text { RY } \\
\text { N }\end{array}$ & $\begin{array}{l}52.5 \% \\
30 \% \\
\mathbf{1 7 . 5 \%}\end{array}$ & $\begin{array}{l}74.5 \% \\
21 \% \\
4.5 \%\end{array}$ & $\begin{array}{l}63 \% \\
24 \% \\
13 \%\end{array}$ \\
\hline $\begin{array}{l}\text { Do you think physiotherapists should have a right to give function- } \\
\text { al diagnosis? }\end{array}$ & $\begin{array}{l}\text { DY } \\
\text { RY } \\
\text { N }\end{array}$ & $\begin{array}{l}62.5 \% \\
35 \% \\
2.5 \% \\
\end{array}$ & $\begin{array}{l}82 \% \\
18 \%\end{array}$ & $\begin{array}{l}61 \% \\
27 \% \\
11 \%\end{array}$ \\
\hline $\begin{array}{l}\text { Do you think physiotherapists should have a duty to keep medical } \\
\text { records? }\end{array}$ & $\begin{array}{l}\text { DY } \\
\text { RY } \\
\mathrm{N}\end{array}$ & $\begin{array}{l}72.5 \% \\
27.5 \% \\
0\end{array}$ & $\begin{array}{l}79 \% \\
18 \% \\
3 \% \\
\end{array}$ & $\begin{array}{l}67 \% \\
30 \% \\
3 \% \\
\end{array}$ \\
\hline
\end{tabular}

OMP group $n=40$ (Tables 3,4)

Half of the study participants replied that they did not know the guidelines of the APP (48\%). The majority of the respondents believed that physiotherapist is a medical profession $(82.5 \%)$, while $25 \%$ of them responded that this is not a profession of public trust and $30 \%$ believed that physiotherapists should not have access to patients' medical records. Nearly half of the respondents in this group replied that physiotherapists should definitely have their professional self-government (45\%), while $17.5 \%$ responded that they should not. According to $70 \%$ of the study participants, a person with Master's degree in physiotherapy should select physiotherapeutic procedures independently, while $15 \%$ of them responded that physiotheraputic procedures should be selected by rehabilitation doctors. $17 \%$ of the respondents replied that physiotherapists should not be allowed to select rehabilitation supporting devices (including orthopaedic equipment). The majority of the study participants appropriately indicated the definition of "functional diagnosis" (85\%). The respondents $(30 \%)$ rather approved of physiotherapists' right to give functional diagnosis independently. Most respondents $(62.5 \%)$ thought that patients should have direct access to physiotherapists without prior medical doctor's order and patients with back pain should first go to a physiotherapist (55\%), general practitioner $(25 \%)$, rehabilitation doctor $(7.5 \%)$, orthopaedist $(12.5 \%)$ or neurosurgeon $(12.5 \%)$. According to $77.5 \%$ of the study participants, physiotherapists should hold criminal responsibility for their professional duties, while $92 \%$ of the respondents replied that physiotherapists should take a 5-year university course.

\section{PT group $(n=67)($ Tables 3,4)}

Over half of the study participants $(60 \%)$ replied that they definitely knew the guidelines of the Act on the Profession of Physiotherapist, while $3 \%$ of the respondents did not know these guidelines. According to $15 \%$ of physiotherapists, procedures should be selected by doctors of 
various specialisations. Within this group, 7\% of the individuals believed it should be done by a rehabilitation doctor. The respondents (22\%) replied that physiotherapists should not have a right to select rehabilitation supporting devices (including orthopaedic equipment). Several individuals from this group $(35 \%)$ were not certain whether patients should have direct access to the services of physiotherapists without prior medical doctor's order. The majority of the respondents (67\%) replied that patients with back pain should first go to a physiotherapist. The remaining participants from this group (33\%) claimed that they should first see a doctor, while the majority of them thought it should be a rehabilitation doctor $(20 \%)$. The fact that physiotherapists should hold criminal responsibility for their professional duties was accepted by $56 \%$ of the respondents, while $8 \%$ did not agree with this idea. Nearly all of the study participants from this group believed that 5-year university course is an appropriate form of education, while $20 \%$ of them did not approve of any form of specialisation in physiotherapy.

P group $(\mathrm{n}=70)($ Tables 3,4$)$

Over half of the study participants from this group did not know the guidelines of the Act on the Profession of Physiotherapist (62\%). Nearly half of the respondents replied that they rather approved of the idea of the professional self-government of physiotherapists $(45 \%)$, while $17 \%$ of the individuals from this group expressed an opposite opinion. More than half of the respondents claimed that a person with Master's degree in physiotherapy should select procedures independently $(57 \%)$. Other individuals believed that physiotherapeutic procedures should be selected by a rehabilitation doctor $(21 \%)$ or general practitioner $(22 \%)$. Direct access to physiotherapists without prior medical doctor's order was approved of by $78.5 \%$ of the respondents. The assumption that orthopaedic equipment should be selected by physiotherapists was declined by $13 \%$ of the study participants from this group. Nearly $30 \%$ of the respondents did not know or falsely indicated the definition of "functional diagnosis". The same percentage of participants were rather in favour of allowing physiotherapists to give functional diagnosis, while $12 \%$ were against this idea. When asked who should be visited first when back pain occurs, patients indicated a physiotherapist (44\%), neurosurgeon
(24\%), rehabilitation doctor (22\%), orthopaedist $(6 \%)$ and general practitioner $(4 \%)$.

A comparative analysis of all the groups revealed statisticallysignificantdifferences regardingopinions on functional diagnosis given by physiotherapists $(p=0.008)$, direct access to physiotherapists $(\mathrm{p}=0.001)$, and the question whether physiotherapy is a medical science $(p=0.02)$. Moreover, the results concerning the definition of functional diagnosis were also statistically significant $(\mathrm{p}=0.003)$.

\section{Discussion}

Despite a common tendency observed during local meetings and on social websites, the results appear optimistic. It may result from the young age of the respondents and the manner in which their opinions were collected, i.e. via email which is less accessible to older individuals. It is also assumed that persons with a positive attitude to the issue engage in completing the questionnaires. While observing the way in which the APP was created, it could be assumed that the lowest support of the implemented changes might stem from a conflict of interests in the OMP group. However, the highest interest was expected from the group directly connected with the introduced changes, i.e. physiotherapists. A noneffective market of medical rehabilitation in Poland regarding low accessibility to services, prolonged waiting time for procedures or disorganisation to a certain extent forced patients to use faster (private) services. Therefore, it is not surprising that among statistically significant results, the highest support of direct access to physiotherapists was expressed by patients.

The respondents from OMP group showed a tendency to treat physiotherapists rather as a group that perform procedures from medical doctor's orders. They did not fully approve of the idea of a self-government, independent diagnosis or direct access to their services. They did not associate physiotherapy with a medical profession or a profession of public trust. The reasons may result from the fact that for many years, the rehabilitation market did not allow educated professionals to be independent in deciding about the course of physiotherapy. The lack of regulations and standards regarding such issues as the requirement to keep medical records by physiotherapists or hold criminal responsibility for their professional duties as well as an unregulated system of education in the 
field of physiotherapy pushed physiotherapists on the margin of decisiveness in the course of planning rehabilitation and expressing their opinions, and constituted major arguments of the opponents of the Act [2]. The lack of support for self-government in the OMP group seems to have only a formal dimension regarding legal records, keeping medical records, etc. The responses clearly suggest that the majority of the respondents from this group approved of the idea of physiotherapists leading and deciding in the process of planning rehabilitation. The lack of complete acceptance of a self-government may be directly connected with the function it serves (article 62 of the Act on the Profession of Physiotherapist), i.e. 1) controlling proper practice of physiotherapists' profession; 2) representing physiotherapists; 3) promoting constant improvement of qualifications among physiotherapists; 4) setting and updating standards and guidelines in physiotherapy; 5) health education and promotion; 6) setting the rules of professional ethics and controlling the way they are observed; protecting professional dignity. A strong self-government may be a more efficient advocate of objectives and competences of the professional group directly connected with it, which, in turn, may not be in line with the interests of the current decision-makers.

Before the APP entered into force, the issue of diagnosing patients by physiotherapists independently had been widely debated; however, their competences were wrongly described [2]. The representatives of medical professions accused the APP project authors of breaking the regulations of the Act on Professions of Doctor and Dentist, which were the only professions granted the right to diagnose [3]. The above research revealed that there was no unified knowledge about functional diagnosis which could be given by physiotherapists. A wrong definition of functional diagnosis being equal to doctor's diagnosis (which means diagnosing the type of a disease, e.g. hemorrhagic stroke, femur fracture) was given by $27 \%$ of the respondents from the $\mathrm{P}$ group, $15 \%$ of the participants from the OMP group and 3\% of the persons from the PT group. Differences in defining functional diagnosis that occurred between the three groups were statistically significant $(p=0.003)$. Functional diagnosis aims at examining motor problem, i.e. motor function disorder in a patient. It is indispensable for determining shortand long-term goals of the therapy and monitoring its effects. The lack of unequivocal approval of physiotherapists' right to make functional diagnosis stands in contrast to article 4 of the APP, according to which, physiotherapists are obliged to pass opinions and diagnoses concerning the functional state of patients, and article 9 of the APP, which imposes an obligation to keep medical records and make them available. The above research revealed that $62 \%$ of the respondents both in the OMP and P groups approved of these competences $(p=0.008)$.

In the group of patients, the majority of the respondents approved of direct access to the services of physiotherapists $(p=0.001)$. It can be transferred to the number of individuals using their services in a private sector. In their report from 2014, the Supreme Audit Office clearly pointed out that despite increased expenditures on rehabilitation procedures, patients had to wait for treatment for a longer period of time, the number of individuals on the waiting list increased and the number of rehabilitation centres decreased [4]. The Polish Chamber of Physiotherapists estimates that to date, $70 \%$ of the procedures have been performed on the private market [5]. The respondents from the group of patients also showed uncertainty regarding the rights and responsibilities of physiotherapists. As the research by the Polish Physiotherapy Association showed, patients were not aware of what this profession involved or assessed it in a wrong way [1]. The lack of social awareness and consistent professional image may lead to confusion among patients and other individuals not connected directly with medicine.

The group of physiotherapists appeared to be most aware of the changes occurring in the rehabilitation sector. The majority of the respondents from this group expressed their full approval regarding medical science $(91 \%)$, public trust $(92.5 \%)$, direct access to services $(97 \%)$, the right to access medical records $(88 \%)$ and self-government (86.5\%). However, previous lack of professional independence led to the fact that the respondents from the PT group approved of other medical groups' interference in planning rehabilitation programmes. Due to the fact that the situation on physiotherapy market is new and detailed guidelines and resolutions have been passed by the Polish Council of Physiotherapists only since the beginning of 2017, there are no comparative publications regarding the opinions of physiotherapists on the APP. 
The World Confederation for Physical Therapy (WCPT) singled out and examined certain parameters which prove the effectiveness of physiotherapists and at the same time determine their rights and responsibilities [6].

The aforementioned guidelines are as follows:

- legal regulation of the profession in a public and private sector,

- the obligation to register in a public-access database,

- unified standards of education,

- the presence of professional self-government or profesional association,

- the notions "direct/early access" meaning access to physiotherapists without prior medical doctor's order.

The notion "self-referral" means independence and more rights granted to physiotherapists, e.g. issuing referrals to other specialists or to diagnostic procedures, giving prescriptions for basic medications or orthopaedic equipment.

Every year, WCPT includes the above factors among major objectives regarding the development of PTE. They quote publications comparing direct access to physiotherapy services with standard procedures and assessing its considerable benefits for the national budget and the patients $[7,8,9]$. It is worth noting that the Act on the Profession of Physiotherapist is a step forward in the realisation of these guidelines, which place our country among the top countries implementing modern physiotherapeutic solutions.

\section{Conclusions}

The Managing Board of the Polish Chamber of Physiotherapists rightly recognised the need for broadly understood education regarding new legal solutions and current trends on the physiotherapy market and included it in the schedule of works for 2017. Workshops or national information meetings are mainly directed to physiotherapists and students of physiotherapy. Also, the need for widespread promotion of this profession in the Polish society, among the representatives of other medical professions as well as abroad was recognised. There is also a need for further research on the opinions of the community on changes in the physiotherapy sector regarding public services, higher education and law.

\section{References:}

1. Stowarzyszenie Fizjoterapia Polska. Raport „Fizjoterapia na świecie od A do Z”; 2013. 1-8 p.

2. Interpelacja $\mathrm{nr}$ 1182, w sprawie zapowiedzi wprowadzenia szkodliwych zmian w ustawie o zawodzie fizjoterapeuty. Lidia Gądek (17-02-2016).

3. Ustawa z dnia 10 grudnia 1998 r. o zmianie ustaw: o zakładach opieki zdrowotnej, o zawodzie lekarza, o zawodach pielęgniarki i położnej, Dz.U. 1998 nr 162 poz. 1115 (1998).

4. Naczelna Izba Kontroli. Raport „Dostępność i finansowanie rehabilitacji leczniczej lata 2011-2013”;2014. 7-13 p.

5. Konferencja prasowa Krajowej Izby Fizjoterapeutów [Internet] Warszawa: „100 dni Krajowej Izby Fizjoterapeutów” [updated 04.2017]. Available from: https://kif.info.pl.

6. Keynote Direct Access [Internet] World Confederation of Physical Therapy [updated 07.2017]. Available from: http://www. wcpt.org/sites/wcpt.org/files/files/Keynote_DirectAccess.pdf.

7. Fritz JM, Brennan GP, Hunter JS. Physical Therapy or Advanced Imaging as First Management Strategy Following a New Consultation for Low Back Pain in Primary Care. Health Serv Res 2015;50(6):1927-32.

8. Rhon D, Fritz JM, Comparative Early Treatment Effectiveness between physical therapy and usual care for low back pain. Rhon and Fritz Trials 2015(16):423:2-9.

9. Fritz JM, Kim J, Thackeray A, Dorius J. Use of Physical Therapy for Low Back Pain by Medicaid Enrollees. Phys Ther 2015;95(12):1668-79. 